\title{
Estefanofilariose em bovinos de corte: relato de casos
}

Joandes Henrique Fonteque, Jackson Schade, Mariana da Silva Casa, Jonatas Carissimi Lovatel, Milena Carol Sbrussi Granella, Renata Assis Casagrande

Centro de Ciências Agroveterinárias, Universidade do Estado de Santa Catarina (UDESC), Lages, SC, Brasil

*Autor correspondente

e-mail: joandes.fonteque@udesc.br

\section{Resumo}

A estefanofilariose é uma enfermidade cutânea causada por nematódeos do gênero Stephanofilaria spp., transmitidos por moscas, como a Musca conducens e Haematobia irritans. Uma vez inoculado o agente, a lesão ocorre com a formação de erupção papular, progredindo para dermatite nodular ulcerativa e exsudação sero-sanguinolenta, que no caso de bovinos pode se manifestar em diferentes regiões. No entanto, ocorre mais comumente na parte cranial do úbere de vacas leiteiras, havendo apenas um relato desta localização em vacas de corte. 0 objetivo do trabalho é a descrição de três casos de estefanofilariose em vacas de corte ocorridos em uma propriedade rural localizada no município de Ipê, RS. Trata-se de três vacas adultas da raça Red Angus em período de lactação, com histórico de lesões pruriginosas na região do úbere e tetos. A propriedade possuía um rebanho de 40 vacas de cria e apresentava histórico de casos semelhantes nos três anos anteriores, ocorridos sempre no período do verão e apresentando remissão clínica no inverno. Ao exame clínico, as lesões foram caracterizadas por ulcerações presentes na porção cranial do úbere, com tamanho variando de 2,0 x 3,0 cm a 2,5 x 4,0cm, sendo que em um animal apresentava-se também no teto do quarto mamário anterior. Havia secreção sero-sanguinolenta e/ou purulenta e crostas hemorrágicas, sendo que em algumas lesões foram observadas larvas de dípteros (miíase). Procedeu-se a colheita de secreção da lesão para realização de esfregaços posteriormente corados com panótico rápido, além de quatro fragmentos de tecido adjacentes à borda da lesão por meio de biopsia com auxílio de punch, sendo um fragmento acondicionado em formol para o exame histopatológico e outros três imersos em solução fisiológica $(\mathrm{NaCl}$ 0,9\%) para o exame direto do sedimento por microscopia. 0 exame histopatológico evidenciou infiltrado de eosinófilos, macrófagos, linfócitos e plasmócitos na derme superficial e profunda, além de proliferação de fibroblastos com moderada quantidade de colágeno e angiogênese. Também se 
observou necrose focalmente extensa na epiderme e em um dos animais foi evidenciada acantose e hiperqueratose difusa moderada na epiderme. Durante a análise microscópica dos esfregaços corados, bem como no exame direto do sedimento de todos os animais, foi evidenciada a presença das microfilárias, confirmando o diagnóstico de estefanofilariose. 0 tratamento consistiu na aplicação tópica de Triclorfon na forma de pasta a $6 \%$, duas vezes ao dia, sendo relatada remissão total das lesões nos três animais após sete dias de tratamento. 0 diagnóstico desta enfermidade em bovinos de corte é o primeiro relatado na literatura no Brasil e ressalta a importância do conhecimento da ocorrência da doença nestes rebanhos e sua inclusão como diagnóstico diferencial com outras enfermidades, bem como para o estabelecimento de estratégias de controle e prevenção evitando importantes prejuízos econômicos. 